\title{
The Social Impact of a WTO Agreement in Indonesia
}

by

Anne-Sophie Robilliard and Sherman Robinson`

Chapter 11 in Putting Development Back into the Doha Agenda: Poverty Impacts of a WTO

Agreement, Thomas W. Hertel and L. Alan Winters (eds) forthcoming from the World Bank, Washington, D.C

World Bank Policy Research Working Paper 3747, October 2005

The Policy Research Working Paper Series disseminates the findings of work in progress to encourage the exchange of ideas about development issues. An objective of the series is to get the findings out quickly, even if the presentations are less than fully polished. The papers carry the names of the authors and should be cited accordingly. The findings, interpretations, and conclusions expressed in this paper are entirely those of the authors. They do not necessarily represent the view of the World Bank, its Executive Directors, or the countries they represent. Policy Research Working Papers are available online at http://econ.worldbank.org.

* Institut de Recherche pour le Développement (IRD) and DIAL, Paris.

- University of Sussex. 


\section{Summary}

Indonesia experienced rapid growth and the expansion of the formal financial sector during the last quarter of the $20^{\text {th }}$ century. Although this tendency was reversed by the shock of the financial crisis that spread throughout Asia in 1997 and 1998, macroeconomic stability has since then been restored, and poverty has been reduced to pre-crisis levels. Poverty reduction remains nevertheless a critical challenge for Indonesia with over 110 million people (53 percent of the population) living on less than $\$ 2$ per day.

The objective of this study is to help identify ways in which the Doha Development Agenda might contribute to further poverty reduction in Indonesia. In order to provide a good technical basis for answering this question, we use an approach which combines a Computable General Equilibrium (CGE) model with a microsimulation model. This framework is designed to capture important channels through which macroeconomic shocks affect household incomes. It allows making recommendations on specific trade reform options as well as on complementary development policy reforms.

The framework presented in this study generates detailed poverty outcomes of trade shocks. Given the magnitude of the shocks examined here and the structural features of the Indonesian economy, only the full liberalization scenario generates significant poverty changes. Their impact is examined under alternative specifications of the functioning of labor markets. These alternative assumptions generate different results, all of which confirm that the impact of the full liberalization on poverty would be beneficial, with wage and employment gains dominating the adverse food price changes that could hurt the poorest households. Two alternative tax replacement schemes are examined. While direct tax replacement appears to be more desirable in terms of efficiency gains and translates into higher poverty reduction, political and practical considerations could lead the Government of Indonesia to choose a replacement scheme through the adjustment of VAT rates across nonexempt sectors. 


\section{WPS3747}

\section{Introduction}

Over the last 30 years, decreasing tariffs in both developed and developing countries, as well as declining transport costs and economic growth have led to a sustained increase in the exports and imports of goods and services by developing countries. While this might have benefited many developing countries, contributing to enhanced productivity growth and the development of the financial sector, it is not obvious whether the poorest households have gained from increased trade liberalization. Such doubts are reinforced by the fact that this liberalization has so far been relatively asymmetric with rich country protection still high in labor intensive sectors such as wearing apparel and agriculture. This asymmetry is further exacerbated by the subsidies provided to OECD farmers by their governments.

Indonesia experienced rapid growth and the expansion of the formal financial sector during the last quarter of the $20^{\text {th }}$ century. After a period of economic slowdown following a financial crisis, macroeconomic stability has been restored and growth picked up, reaching 5.1\% in 2004. Poverty reduction remains nevertheless a critical challenge for Indonesia with over 110 million people (53 percent of the population) living on less than $\$ 2$ per day.

The objective of this study is to help identify ways in which the Doha Development Agenda might contribute to further poverty reduction in Indonesia. In order to provide a good technical basis for answering this question, we use an approach which combines a Computable General Equilibrium (CGE) model with a microsimulation model. This framework is designed to capture important channels through which macroeconomic shocks affect household incomes. It will allow making recommendations on specific trade reform options as well as on complementary development policy reforms. 
This chapter is organized as follows. First, we present some features of the Indonesian economy, in particular with regards to trade. Second, we present the analytical framework developed to analyze the impact of further trade liberalization on poverty and income distribution. Third, we present and comment on the simulation results. In the fourth section, we examine some of the key assumptions made in the reference scenario and explore the impact of trade reform on poverty when these are relaxed. The last section concludes.

\section{Economic and Policy Environment}

Table 1 shows that Indonesia's overall openness to foreign trade is relatively high, with exports (imports) amounting to more than 37 percent (28 percent) of GDP. Not surprisingly, Table 1 also shows that trade "exposure" is heterogeneous across sectors. Indonesia's trade appears to be concentrated in petroleum and manufactured products. On the other hand, agricultural sectors appear to be weakly "exposed" to trade, contributing very little to total exports and imports, a result of Indonesia's export diversification towards manufacturing products. The textile and wearing apparel industry contribution to exports is significant (12.7 percent) and that sector's exposure to trade is important, with an export ratio of 41.4 percent and an import ratio of 20.0 percent. Overall, the most exposed non-oil sectors appear to be the wood and wood products industry; the paper printing, transport equipment \& metal products industries; and the chemical fertilization, clay products, cement and basic metal manufacturing industries.

Official data from the WTO Secretariat indicate that average applied MFN tariffs declined between 1998 and 2002, reflecting mainly unilateral cuts over this period (WTO, 2003). While more than 90 percent of Indonesia's tariffs are bound, there remains a large gap between bound and applied rates (35 percentage points, on average). Almost all applied rates are ad 


\section{WPS3747}

valorem and there are no tariff quotas. Nevertheless, the scope of import restrictions and licensing appears to have increased through new special import licensing from 2002. These affect sensitive products such as rice and sugar and are granted based on domestic needs. It should be noted that the new government is looking into removing or reducing these licenses. Import duties across commodities in the base year appear to be relatively low, with values ranging from 1.5 percent for nonfood crops to 6.6 percent for textile and wearing apparel products. These low values hide somewhat higher values for very specific products that cannot be captured given the level of aggregation of commodities in the data base used here. Despite these higher tariffs, Indonesia has overall low tariffs, including in agriculture.

The contribution of tariffs to Indonesia's tax revenue is also an important question. Tariffs accounted for 6.0 percent of government revenue, and corresponded to 0.8 percent of GDP in 2002, the base year chosen as the starting point of our model. While Indonesia's budget does not appear to be highly dependent on import duties, the tax replacement scheme could potentially alter the impact of trade liberalization, depending on the choice of replacement tax used.

Despite its economic recovery since the 1998 crisis, over 110 million people (53 percent of the population) are still living on less than $\$ 2$ per day. Using Indonesia’s official poverty lines, poverty incidence was 18.2 percent in 2002 at the national level, with higher levels in the rural (21.2 percent) than in the urban sector (14.5 percent). As a consequence, two-thirds of the poor in Indonesia live in the rural sector. Full liberalization of the rest of the world, particularly the removal of domestic agricultural support in OECD countries, is expected to lead to an increase in the prices of agricultural products. The impact on agricultural households should be positive, but the impact on poverty depends on whether poor agricultural households are net buyers or net 
sellers of food products. Of course, the size of the domestic market and the resulting low exposure of agricultural sectors to foreign trade mentioned above are likely to dampen the impact of world price changes on the domestic market. In the urban areas, poor households could suffer from an increase in the price of food. The resulting overall poverty impact is thus difficult to predict and depends on the relative size of the efficiency and hence income gains generated by the removal of the import duties, and changes in the relative price of food.

\section{Analytical Framework: A Macro-Micro Model for Indonesia}

This section describes the specification of the Indonesia Macro-Micro Model used to analyze the social impact of various trade liberalization scenarios. A more detailed discussion of the specification and econometric estimates of the various equations of the household income generation model and simulation methodology may be found in Bourguignon, Robilliard, and Robinson (2003).

Our approach combines a micro-simulation model with a Computable General Equilibrium (CGE) model in a sequential fashion. The term micro-simulation spans a number of different approaches used in the social sciences. Their common denominator is to focus primarily on the economic behavior of agents and investigate the impact of public policy and shocks at the micro level. These models typically take representative samples of micro agents (households or firms) and measure the effect of government policy on these samples. Various micro-simulation techniques are described in more detail in the annex to the associated working paper (see also Cogneau et al. 2003). ${ }^{1}$

\footnotetext{
${ }^{1}$ The interested reader is referred to the World Bank Policy Research Working Paper version of this chapter which has an extensive discussion of alternative approaches to micro-simulation.
} 


\subsection{Specifications of the Indonesia CGE model}

The CGE model is based on a standard Social Accounting Matrix and is designed to capture structural features of the economy as well as the general equilibrium effects of the macro constraints arising from macro-economic shocks. The model was developed from the neoclassical-structuralist modeling tradition originally presented in Dervis et al. (1982). It is formulated as a set of simultaneous linear and non-linear equations, which define the behavior of economic agents, as well as the economic environment in which these agents operate.

Indonesia's economy is dualistic, which the model captures by distinguishing between formal and informal activities in each sector. The two sub-sectors differ in the type of factors they use. This distinction allows treating formal and informal factor markets differently. For all activities, the production technology is represented by a set of nested CES (constant-elasticityof-substitution) value-added functions and fixed coefficient (Leontief) intermediate input relationships. On the demand side, consumers purchase a composite good and imperfect substitutability is assumed between formal and informal products of the same commodity. Domestic prices of commodities are flexible, allowing markets to clear in a competitive setting where individual suppliers and demanders are price-takers.

Following Armington (1969), the model assumes imperfect substitutability, for each good, between imports and the corresponding composite domestic commodity. For export commodities, the allocation of domestic output between exports and domestic sales is determined on the assumption that domestic producers maximize profits subject to imperfect transformability between these two alternatives. The composite production good is a CET (constant-elasticity-of-transformation) aggregation of sectoral exports and domestically consumed products. The trade elasticities used to calibrate the functions used in the CGE model 
were taken from version 6 of the GTAP data base. These have recently been econometrically estimated for at the disaggregated GTAP commodity level (Hertel et al., 2004).

There are eight labor categories in the Indonesia CGE model: Urban Male Unskilled, Urban Male Skilled, Urban Female Unskilled, Urban Female Skilled, Rural Male Unskilled, Rural Male Skilled, Rural Female Unskilled, and Rural Female Skilled. The distinction between rural and urban labor implies that workers are not allowed to shift between rural and urban production sectors. Male and female, as well as skilled and unskilled labor, are assumed to be imperfect substitutes in the production activity of urban or rural sectors. Alternative specifications of the functioning of the labor markets can be implemented in the model. In the reference simulations, wages are assumed to adjust so as to clear all labor markets. This is consistent with the full employment assumption used in the global model. Two alternative specifications will also be examined.

Land appears as a factor of production in the agricultural sectors. Only one type of land is considered in the model, while capital markets are segmented into six categories: owner occupied housing, other unincorporated rural capital, other unincorporated urban capital, domestic private incorporated capital, public capital, and foreign capital. Given the medium-term perspective of the model, it is assumed that land is activity specific, while other types of capital are competitively allocated among the different sectors so that its marginal value product is equalized across activities.

Equilibrium in a CGE model is defined by a set of constraints that need to be satisfied by the economic system but are not considered directly in the decisions of micro agents. Aside from the supply-demand balances in product and factor markets, three macroeconomic balances are specified in the Indonesia CGE model: (i) the fiscal balance, with government savings equal to 
the difference between government revenue and spending; (ii) the external trade balance (in goods and non-factor services), which implicitly equates the supply and demand for foreign exchange; and (iii) savings-investment balance. We assume that savings are investment driven and adjust through flexible saving rates for firms, that foreign savings are in fixed supply with the demand for foreign exchange equated through an endogenous exchange rate, and that government income is also fixed with lost tariff revenue replaced through a variable tax rate on households. This closure is expected to be relatively "neutral" in terms of the distributive impact of the shocks implemented. An alternative tax replacement scheme will be also examined.

The original CGE model was constructed to reflect Indonesia's economic pre-crisis situation and is based on a 1995 Social Accounting Matrix (SAM). In order to capture the postcrisis structural features of the Indonesian economy, the 1995 Indonesia SAM was updated using cross-entropy methods (see Robinson et al., 2001). The updating procedure imposes the following pieces of information from 2002: value-added by activity; the structure of imports and exports by commodity; and the data contained in a macro SAM. Table 2 summarizes the aggregate values of the resulting $2002 \mathrm{SAM}^{2}$

\subsection{Specification of the Indonesia microsimulation model}

The microsimulation model is based on household and individual level data from the SKTIR survey for the year 1996 and simulates income generation mechanisms for 9,800 households corresponding to 42,400 individuals. ${ }^{3}$ Four occupational choices are distinguished at the individual level: (i) inactivity, (ii) wage work, (iii) self employment, and (iv) multi-activity

\footnotetext{
${ }^{2}$ The fully disaggregated SAM used has 39 activity accounts and 22 commodity accounts. Full detail is presented in Chapter Annex A.

${ }^{3}$ The Special Survey on Saving and Household Investment (SKTIR) was integrated as a part of a module (submodule) of the SUSENAS survey. It was only administered to a sub-sample of the SUSENAS sample.
} 


\section{WPS3747}

(wage work and self employment). All individuals aged 15 years and older are assumed to participate in the occupational choice. Following McFadden's approach to discrete choice behavior (1974) we assume that an individual chooses the outcome that maximizes the utility gained from that choice. It is also assumed that the occupational choice behavior of household heads is different from that of spouses or other members of the household. More specifically, we posit that the decision process is sequential and that occupational choices for spouses and other members depend on characteristics of the household head and on his or her occupational choice.

The microeconomic database of the original Indonesia model is the 1996 SUSENAS SKTIR Household survey on investment and savings. All individuals aged 10 years and older were interviewed on their sources of income. The sample is updated using a cross-entropy approach (Robilliard and Robinson 2003). This method generates new sets of household statistical weights that are consistent with projected population and structure of the labor force for 2002. Changes in the labor force structure are based on observed changes in the 1996 and 1999 SAKERNAS labor force surveys.

The two models are solved separately. The "macro" or CGE model communicates with the micro-simulation model by generating a vector of prices, wages, and aggregate employment variables corresponding to a given shock or policy. Then the micro-simulation model is used to generate changes in individual wages, self-employment incomes and employment status in a way that is consistent with the set of macro variables fed by the macro model. When this is done, the full distribution of real household income corresponding to the simulated shock or policy may be evaluated. Consistency of the microsimulation model with the equilibrium of aggregate markets in the CGE model requires that three conditions hold. First of all, changes in average earnings with respect to the benchmark in the micro-simulation module must be equal to changes in wage 
rates provided by the CGE model for each labor-market category. Secondly, changes in agricultural and nonagricultural self-employment income in the micro-simulation module must be equal to changes in the corresponding income per worker provided by the CGE model. And finally, changes in the number of wage workers and self-employed workers by labor-market category in the micro-simulation model must match those same changes generated by the CGE model.

\section{Implementation and Analysis of Trade Policy Shocks}

Various scenarios are examined in order to inform the Doha Development Agenda negotiations. These scenarios are built upon the work laid out in chapters 2 and 3 of this volume and entail shocks to Indonesia's import prices, export prices and tariffs. ${ }^{4}$ In the case of Indonesia, the pre-experiment outlined in Chapter 3 was also quite important. Recall that is was designed in order to take into account China's accession to the WTO, the completion of the UR-ATC commitment to abolish textiles and apparel quotas, as well as EU's enlargement to 25. This simulation (PRESIM) is given explicit attention in this chapter, as it generates a new base from which all subsequent liberalizations simulations will start.

The employment and earnings impacts generated by the CGE model are fed into the microsimulation model. ${ }^{5}$ As described above, the microsimulation is used to generate a new distribution of income which can then be compared to the base distribution. Both poverty and inequality indicators are presented and poverty indicators are computed using official poverty

\footnotetext{
${ }^{4}$ More details of the shocks fed into the CGE model are given in Annex B of the World Bank Policy Research Working Paper version of this paper. Since the Indonesia model assumes export prices are exogenous and fixed, we diverge from the approach outlines in Chapter 3, and simply shock export prices. It should be noted that this specification gives this model a zero optimal tariff, unlike that implicit in the GTAP simulations.

${ }^{5} \mathrm{~A}$ total of 32 variables generated by the CGE model are fed into the microsimulation module.
} 


\section{WPS3747}

lines. ${ }^{6}$ The macroeconomic and social impacts of the first set of scenarios are presented in Tables 3 and 4.

We first examine the impact of the pre simulation scenario (PRESIM). The aggregate real impact is small and negative. Private consumption decreases by 0.2 percent. Imports and exports also decrease by 1.4 and 1.0 percent respectively. These results stems from a slight deterioration of the terms of trade facing Indonesia as the demand for its exports fall in the wake of quota elimination and is driven by the fact that the estimated quota rents in the initial data base are much larger on China than on other textile exporting countries like Indonesia (François and Spinanger, 2004). At a more disaggregated level, the shock leads to some reallocation of factors across sectors. Not surprisingly, the textile and wearing apparel faces the worst terms of trade shock, with export prices falling by 3.8 percent and import prices increasing very slightly. As a result, value added from the textile and wearing apparel sectors decreases by more than 30 percent and factors of production are reallocated towards other manufacturing sectors.

At the household level, the poverty and inequality impacts are relatively small. However, these results likely underestimate the cost of reallocation suffered by workers in the textile and wearing apparel sector. While these costs are not captured by the model, some displaced workers could suffer, at least temporarily, from unemployment, particularly since they are likely to come from informal sectors that do not provide unemployment benefits.

Starting from the updated base year generated with the PRESIM scenario, the full trade liberalization impact is examined through a set of 3 simulations. In the first one, we examine the impact of unilateral liberalization of Indonesia (ULIB); in the second, we consider the impact of

\footnotetext{
${ }^{6}$ The use of official poverty lines gives a much lower incidence of poverty than the \$2 per day mark, and hence less scope for change.
} 


\section{WPS3747}

full liberalization excluding Indonesia (FLIBX); finally, in the third scenario, we analyze the combined impact of full liberalization including Indonesia (Full-Lib).

Unilateral liberalization, whereby Indonesia cuts all the duties facing imports from the rest of the world, has some impact on "nominal" GDP ${ }^{7}$ and generates an increase in both exports and imports. At the sector level, there is some reallocation of factors out of the textile and wearing apparel sector and towards the paper printing, transport equipment and metal products industries. Although the removal of imports tariff hurts the sectors that benefited from higher relative protection levels, the total impact on household income is positive, as can be seen from Table 4. Per capita income increases by 0.6 percent at the national level, a number which is consistent with the increase in "nominal” GDP.

Results suggest that unilateral liberalization would generate an increase in the average per capita household income of 0.6 percent and that the impact on the distribution of income would be negative but small. As a result of the average per capita income increase, poverty decreases modestly. The poverty headcount decreases by 1.0 percent at the national level (from 18.3 to 18.1 percent) and the impact appears higher in the urban areas. Higher order poverty indicators vary by the same magnitude, a result that indicates that the poorest of the poor also benefit from the unilateral liberalization, despite with the slight worsening in the distribution of income. Overall, these changes translate into a total of 375,000 people escaping poverty.

As a result of full trade liberalization in the rest of the world, the Indonesian economy faces decreasing import and export prices but an improvement in overall terms of trade: while the export price index decreases by 0.6 percent, the import price index decreases by 2.3 percent.

\footnotetext{
7 "Nominal" GDP is computed with respect to the Consumer Price Index (CPI). Since the CPI is the appropriate numéraire for the analysis conducted at the household level, nominal GDP is the macro aggregate which changes are consistent with the changes in per capita income at the household level. Also note that poverty and inequality indicators in the microsimulation module are based on total per capita earned income, with no deduction of direct taxes. The issue of tax replacement will be debated in subsequent simulations.
} 
Despite this average decrease, import prices for agricultural goods increase. The impact on nominal GDP at factor cost is positive and both imports and exports increase by 4.3 and 2.1 percent respectively. In terms of absorption components, both government consumption and investment are assumed to be fixed while private consumption increases by 0.7 percent. At the sector level, changes are driven by the differential exposure to foreign trade and the terms of trade shocks and some reallocation of factors occurs, mainly between manufacturing activities. These shocks translate into a 0.5 percent increase in per capita income at the household level. The increase is much smaller in the urban sector and is accompanied by a worsening in the income distribution. As a result, the poverty impact is small in terms of incidence and both the poverty gap and squared poverty gap increase, suggesting that some of the poorest households fare badly. ${ }^{8}$ This result stems from the adverse impact on urban households of rising food prices. Results in the rural sector are quite very different, with a 0.9 percent increase in the average per capita income and almost no change in inequality indicators. As a result, close to 690,000 people are lifted out of poverty in the rural area when the rest of the world liberalizes trade.

The full liberalization scenario (Full-Lib) combines ROW and Indonesian reforms and generates more favorable aggregate results with exports and imports increasing by 5.9 and 9.1 respectively. Total employment is assumed to fixed, but the full liberalization entails some reallocation of labor towards self employment for each labor category, namely a reallocation of labor out of formal sectors and towards agricultural sectors. This stems from the fact that import prices for nonagricultural good decrease more than for agricultural products as a result of the full liberalization. As a consequence there is an improvement in the distribution of income overall, as well as within urban and rural areas. Consequently poverty falls with nearly 1,400,000 people

\footnotetext{
${ }^{8}$ The poverty gap measures the distance between of the average poor household income per capita and the poverty line while the squared poverty gap gives a measure of the distribution of income among poor households.
} 
escaping poverty, a number resulting from the drop in the incidence of poverty from 18.3 to 17.7 percent.

The final scenario explored in Tables 3 and 4 is the core Doha scenario. In the case of Indonesia, the impacts are very small - just a 0.1 percent impact on per capita consumption - and less than a one percent rise in aggregate imports and exports. There is a negligible impact on inequality, but rising incomes boost about 50,000 people out of poverty according to the model predictions.

\section{Examining Alternative Scenarios}

A number of alternative scenarios are examined in this section. They are aimed a exploring the importance of some of the assumptions made in the reference simulations regarding labor markets, as well as the choice of tax instrument for the replacement of tariff revenue.

\subsection{Tax replacement scheme}

In the reference simulation, direct taxes on household income are adjusted in an equiproportionate manner to compensate for the revenue loss due to the cut in import duties. This was done to permit comparability with other studies in this volume. While this type of tax replacement scheme would be very efficient, it would entail a major fiscal reform which is unlikely to occur in the current political and practical context in Indonesia. ${ }^{9}$ Therefore, we now

\footnotetext{
${ }^{9}$ Personal tax rates range from 5 percent for the lowest bracket to 35 percent for the highest. All rates except the highest were lowered in 2001.
} 
turn to the impact of trade reform under an alternative tax replacement scheme whereby value added rates adjust to make up for the revenue loss. ${ }^{10}$

As mentioned above, import tariffs accounted for 6.0 percent of government income and 0.8 percent of GDP in 2002. The contribution of the VAT government revenue was 6 times higher - representing 36.5 percent of government income and 4.6 percent of GDP. The compensation of lost revenue through the adjustment of VAT results in a 17 percent increase in rates across non-exempt sectors.

Turning to Tables 5 and 6, we see that the increase in trade volume is comparable under the VAT replacement tax. However, the outcome in terms of efficiency gains is much smaller. In the urban sector, the lower per capita income gain is accompanied by a slight worsening of the distribution of income. The resulting poverty reduction amounts to 2.3 percent, with lesser rates of poverty reduction for the higher order poverty indicators. Overall, 900,000 people are lifted out of poverty instead of the 1,400,000 with the direct tax replacement scheme.

\subsection{Labor markets}

The results of the simulations examined in the previous section rested on the assumption of fixed employment in all labor markets. That assumption led to modest changes in growth and welfare at the household level. In this section, we examine the impact of the full liberalization scenario with two alternative specifications of labor market functioning. In the first alternative closure, hourly wages are assumed to be fixed with labor markets clearing through the adjustment of total employment (FLIB_2). This specification is expected to generate higher aggregate welfare effects, as previously idle resources are brought into play. In a second

\footnotetext{
${ }^{10}$ VAT rates are relatively homogeneous across nonexempt sectors. It is assumed that informal sectors are not subjected to VAT due to the difficulty of collecting these taxes at the level informal production units.
} 


\section{WPS3747}

specification, employment is assumed to be fixed - not only in the aggregate - but also by sector (FLIB_3). With less flexibility, we expect this sector-specific labor scenario to generate lower aggregate welfare gains.

In the case of flexible unemployment, the growth impact is higher than under the full employment assumption. It is driven by an increase in employment of approximately 1.4 percent ranging from 1.0 percent to 1.8 across labor categories. As a result, the employment changes fed into the microsimulation model are bigger. This generates higher per capita income changes but while the overall impact on distribution remains positive, it deteriorates in the urban area. This leads to smaller changes in poverty in the urban area where the poverty headcount decreases only by 1.2 percent despite the higher per capita increase. As a consequence, the aggregate poverty reduction is somewhat smaller under this unemployment closure $(-1,260,000)$ than under the reference scenario.

How can it be that a scenario in which unemployment falls generates a smaller poverty reduction than one in which unemployment is fixed? The answer is that it all depends on who gets the jobs. If the jobs go to second- or third-earners in non-poor households, then the income distribution can worsen, as the pool of unemployed keeps wages from rising and therefore mitigates the benefits to households for which the number of wage earners is fixed. Of course the issue of who gets the new jobs is subject to considerable uncertainty, and this is reflected in the random draws for the error term associated with the occupational choice model. Therefore there is clearly a need for Monte Carlo analysis - a topic to which we will turn momentarily.

Under the sector-specific labor assumption, there is no reallocation of labor across sectors and efficiency gains are smaller. The resulting poverty outcomes are also smaller and overall 
income distribution worsens due to a smaller improvement of per capita income in rural areas relative to urban areas.

\subsection{Monte Carlo Analysis}

Given the stochastic nature of the occupational choice model in the microsimulation model, it makes sense to perform Monte Carlo experiments to examine the sensitivity of poverty and income distribution outcomes. ${ }^{11}$ Is it possible that the poverty outcome discussed above in the case of the unemployment closure is not robust? Therefore, we perform Monte Carlo experiments on the full liberalization scenario under the three alternative labor market closure specifications, namely the fixed employment closure (Full-Lib), the flexible employment closure (FLIB_2) and the sector specific labor closure (FLIB_3).

The Monte Carlo results presented in Table 7 give us a much better idea of the robustness of the findings presented in Tables 4 and 6. Firstly, note that the magnitude of the standard deviation on the inequality indicators suggests that the changes in income distribution are not significantly different from zero in any simulation. Moreover, once we consider the full range of possible outcomes in the occupational choice model, the sign of difference in the poverty outcome between the fixed employment specification and the flexible employment closure is reversed. Under the flexible employment closure, the trade liberalization scenario generates higher poverty reductions. However, the size of the standard deviation on the poverty outcomes suggests that the difference in poverty outcomes under the reference scenario and the flexible

11 The term Monte Carlo experiments refers here to the replication of microsimulation results using different draws of the residuals for the occupational choice model as well as for the wage equation model. One hundred draws were performed for each simulation. The draws that did not generate a feasible solution where dropped, which explains why the number of observations is smaller than 100 in Table 7. 
unemployment closure may not be significant. On the other hand, it is clear that the third case that of fixed labor - does generate significantly smaller poverty reduction.

Of course any model is an abstraction of reality and labor markets in Indonesia probably don't function precisely in the manner described under any of the three alternative specifications depicted above; rather they are likely to reflect of combination of these polar views of the world. Therefore, these results should be viewed as providing a range of plausible poverty outcomes subject to the other assumptions embedded in the model.

\section{Summary and Conclusions}

The framework presented in this study has permitted us to generate detailed poverty outcomes resulting from international trade shocks. Given the magnitude of the shocks examined here, and the structural features of the Indonesian economy, only the full liberalization scenarios generate significant poverty changes. Their impacts are examined under alternative specifications of the functioning of labor markets. These assumptions generate quite different results but all conclude that the impact on poverty of full liberalization would be positive, with efficiency and income gains dominating the adverse food price changes that could hurt the poorest households. Results also suggest that poverty reduction would be higher in the rural than in the urban sector. Two alternative tax replacement schemes are examined. While the direct tax replacement appears to be more desirable in terms of efficiency gains and translates into higher poverty reduction, political and practical considerations could lead the Government of Indonesia to choose a replacement scheme through the adjustment of VAT rates across non-exempt sectors. Such a move would dampen the poverty reducing potential of trade reform. 


\section{WPS3747}

As with any such study, there are a number of important limitations to this work. First of all, one should keep in mind that our results are likely to underestimate the cost of temporary unemployment endured by displaced workers in some sectors - particularly in light of the fact that unemployment benefits are not available for most Indonesian workers. Of course, these costs could be mitigated by phasing the trade reforms in gradually. And they would be further diminished if these trade reforms raised the overall growth rate of the Indonesian economy. Such dynamic growth gains - fueled by increased productivity and investment - have been ignored here, but are addressed in the final three chapters of this volume. 


\section{References}

Bourguignon, F., A.S. Robilliard, and S. Robinson. 2003. "Representative versus real households in the macro-economic modeling of inequality" Forthcoming in Kehoe T., Srinivasan T.N., Whalley J. (eds), Frontiers in Applied General Equilibrium Modeling: Essays in Honor of Herbert Scarf.

Cogneau, D., M. Grimm, and A.S. Robilliard. 2003. "Evaluating Poverty Reduction Policies: The Contribution of Microsimulation Techniques.” In Cling J.-P., M. Razafindrakoto, and F. Roubaud, eds., The New International Strategies for Poverty Reduction. London: Routledge.

Dervis, K., J.de Melo, and S. Robinson. 1982. General Equilibrium Models for Development Policy. New York: Cambridge University Press.

Essamah-Nssah, B. 2004. "Building and Running General Equilibrium Models in EViews", Policy Research Working Paper no. 3197, World Bank.

François, J. and D. Spinanger. 2004. "ATC Export Tax Equivalents” in GTAP v. 6 data doco (https://www.gtap.agecon.purdue.edu/databases/v6/v6_doco.asp).

Hertel, T., D. Hummels, M. Ivanic, and R. Keeney. 2004. "How Confident Can We Be in CGEBased Assessments of Free Trade Agreements?” GTAP Working Paper No. 26.

Ivanic, M. 2004.

McFadden, D. 1974. "Conditional Logit Analysis of Qualitative Choice Behavior.” In P. Zarembka, ed., Frontiers in Econometrics, 105-142. Academic Press: New York.

Robilliard, A.S. and S. Robinson. 2003. "Reconciling Household Surveys and National Accounts Data Using a Cross Entropy Estimation Method”, Review of Income and Wealth, 49(3).

Robinson, S., A. Cattaneo and M. El-Said. 2001. "Updating and estimating a social accounting matrix using cross entropy methods.” Economic Systems Research, 13 (1): 47-64.

Winters, L. Alan. 2000. “Trade, Trade Policy, and Poverty: What are the Links?” World Economy 25(9): 1339-67.

WTO (World Trade Organization). 2003. Trade Policy Review - Indonesia 2003, Geneva: WTO.

World Bank. 2003. Indonesia Development Policy Report: Beyond Macroeconomic Stability. Report No. 27374-IND. Washington: The World Bank. 


\section{WPS3747}

\begin{tabular}{|c|c|c|c|c|c|c|}
\hline & \multicolumn{2}{|c|}{ Exports } & \multicolumn{2}{|c|}{ Imports } & \multicolumn{2}{|c|}{ Parameters } \\
\hline & $\begin{array}{l}\text { Shares } \\
\text { of total } \\
\text { exports }\end{array}$ & $\begin{array}{l}\text { Exports as } \\
\text { a percent } \\
\text { of sector } \\
\text { output } \\
\end{array}$ & $\begin{array}{l}\text { Shares } \\
\text { of total } \\
\text { imports }\end{array}$ & $\begin{array}{l}\text { Imports as a } \\
\text { percent of } \\
\text { composite } \\
\text { good supply }\end{array}$ & $\begin{array}{l}\text { Armington } \\
\text { Elasticities }\end{array}$ & $\begin{array}{c}\text { Import } \\
\text { Tariffs } \\
\text { rates }\end{array}$ \\
\hline Farm Food Crops & 0.1 & 0.2 & 2.4 & 7.7 & 4.7 & 2.2 \\
\hline Farm Nonfood Crops & 0.6 & 6.2 & 0.0 & 0.3 & 5.9 & 1.5 \\
\hline Livestock Products & 0.0 & 0.1 & 0.5 & 2.7 & 7.1 & 3.1 \\
\hline Forestry and Hunting & 0.1 & 2.0 & & & 5.0 & 0.0 \\
\hline Fishery, Drying, and Salting of Fish & 0.3 & 3.1 & 0.0 & 0.1 & 2.5 & 6.2 \\
\hline TOTAL AGRICULTURE & 1.1 & & 2.9 & & & \\
\hline Coal, Metal Ore, Petroleum, and Natural Gas & 17.9 & 63.0 & 2.2 & 16.2 & 10.1 & 1.8 \\
\hline Other Mining and Quarrying & 0.1 & 3.1 & 0.4 & 6.6 & 1.8 & 1.5 \\
\hline Food, Beverages and Tobacco Manufacturing & 7.3 & 11.2 & 3.7 & 4.9 & 4.3 & 6.2 \\
\hline Spinning, Textile, Leather and Wearing Apparel Manufacturing Products & 12.7 & 41.4 & 5.2 & 20.0 & 7.6 & 6.6 \\
\hline Wood and Wood Products & 8.4 & 58.9 & 0.2 & 2.8 & 6.8 & 4.9 \\
\hline Paper Printing, Transport Equipment, Metal Products, and Other Manufacturing Products & 15.7 & 37.9 & 42.7 & 57.2 & 7.6 & 3.0 \\
\hline Chemical Fertilization, Clay Products, Cement, and Basic Metal Manufacturing Products & 21.3 & 36.1 & 27.1 & 37.0 & 6.8 & 2.9 \\
\hline TOTAL INDUSTRY & 83.5 & & 81.4 & & & \\
\hline Whole Sale, Retail Trade, Transport, Storage, and Warehousing & 1.0 & 2.2 & 0.8 & 1.6 & 3.8 & 0.0 \\
\hline Restaurants & 1.4 & 7.5 & 0.6 & 3.1 & 3.8 & 0.0 \\
\hline Hotel and Lodging Places & 4.0 & 44.0 & 1.1 & 17.1 & 3.8 & 0.0 \\
\hline Road Transport and Railways & 1.6 & 8.5 & 1.0 & 5.7 & 3.8 & 0.0 \\
\hline Air and Water Transport and Communications & 5.3 & 28.8 & 4.7 & 25.6 & 3.8 & 0.0 \\
\hline Banking and Insurance & 0.6 & 5.5 & 1.9 & 14.5 & 3.8 & 0.0 \\
\hline Real Estate and Business Services & 0.1 & 0.4 & 2.5 & 10.6 & 3.8 & 0.0 \\
\hline Public Administration, Defense, Social, Recreational, and Cultural Services & 1.2 & 3.0 & 2.0 & 5.1 & 3.8 & 0.0 \\
\hline Personal Household and Other Services & 0.2 & 1.7 & 1.2 & 8.4 & 3.8 & 0.0 \\
\hline TOTAL SERVICES & 15.4 & & 15.7 & & & \\
\hline
\end{tabular}

Source: Updated Social Accounting Matrix 2002, GTAP v.6 and authors’ calculations. 
WPS3747

Table 2: A Macroeconomic SAM for Indonesia (in 2002 Billion Rupiah)

\begin{tabular}{|c|c|c|c|c|c|c|c|}
\hline & Activity & Commodity & Household & Government & World & Investment & Total \\
\hline Activity & & $1,610,012$ & & & & & $1,610,012$ \\
\hline Commodity & & & $1,042,148$ & 132,219 & 569,962 & 325,334 & $1,744,329$ \\
\hline Household & $1,538,826$ & & & & 19,246 & & $1,558,072$ \\
\hline Government & 71,186 & 12,005 & 110,845 & & & & 194,036 \\
\hline World & & 447,626 & & & & & 447,626 \\
\hline Investment & & & 405,079 & 61,817 & $-141,562$ & & 325,334 \\
\hline Total & $1,610,012$ & $2,069,643$ & $1,152,993$ & 132,219 & 589,208 & 325,334 & \\
\hline
\end{tabular}

Source: LDB on Line (World Bank), taken from Essama-Nssah, 2004.

Table 3: Macroeconomic results of trade liberalization reference scenarios

\begin{tabular}{l|rrrrrrr}
\hline & \multicolumn{1}{|c}{ Base } & PRESIM & New base & ULIB & FLIBX & Full-Lib & Doha \\
\hline Private Consumption & 1042.1 & -0.2 & 1040.3 & 0.0 & 0.7 & 0.7 & 0.1 \\
Investment Demand & 325.3 & & 324.7 & & & & \\
Government Consumption & 132.2 & & 132.2 & & & & \\
Total Absorption & 1499.7 & -0.1 & 1497.3 & 0.0 & 0.5 & 0.5 & 0.1 \\
Exports value & 569.9 & -1.0 & 566.0 & 4.6 & 2.1 & 0.9 & 9.1 \\
Imports value & 447.6 & -1.4 & 443.1 & 5.9 & 4.3 & 0.8 \\
Real GDP at Factor Costs & 1538.8 & -0.1 & 1537.8 & 0.0 & 0.0 & 0.0 & 0.1 \\
Nominal GDP at Factor Costs & 1538.8 & -0.1 & 1537.8 & 0.8 & 0.4 & 1.2 & 0.0 \\
Urban Agricultural Income & 112.3 & 0.7 & 113.1 & 0.0 & 2.5 & 3.3 & 0.1 \\
Rural Agricultural Income & 208.7 & 0.6 & 210.0 & -0.2 & 2.5 & 3.0 & 0.5 \\
Urban Non Agricultural Income & 182.5 & 0.3 & 183.0 & 1.4 & 0.4 & 1.8 & 0.6 \\
Rural Non Agricultural Income & 112.3 & -0.5 & 111.7 & 0.9 & 0.7 & 1.5 & 0.0 \\
Urban Unskilled Wage Income & 223.3 & -0.3 & 222.5 & 1.0 & 0.1 & 0.9 & 0.1 \\
Rural Unskilled Wage Income & 43.6 & -0.1 & 43.6 & 0.8 & 0.1 & 1.0 & 0.0 \\
Urban Skilled Wage Income & 77.2 & -0.2 & 77.0 & 1.0 & 0.3 & 1.3 & 0.0 \\
Rural Skilled Wage Income & 67.0 & -0.1 & 67.0 & 0.6 & 0.6 & 1.2 & 0.0 \\
\hline Non Labor Income & 603.1 & -0.2 & 601.8 & 1.0 & -0.4 & 0.4 & 0.1 \\
\hline
\end{tabular}

Notes: 1.Base and new base values in Rp. thousands of billions; percent changes for the nonbase columns.

2. PRESIM = Pre-simulation scenarios entailing China's WTO accession, the completion of the UR-ATC commitment to abolish textiles and apparel quotas, and EU's enlargement to 25 members; ULIB = Unilateral liberalization; FLIBX = Full liberalization excluding Indonesia; FLIB = Full liberalization including Indonesia. Doha = Doha scenario. 
WPS3747

Table 4: Social impact of trade liberalization reference scenarios

\begin{tabular}{|c|c|c|c|c|c|c|c|}
\hline National level & Base & PRESIM & New base & $U L I B$ & FLIBX & Full-Lib & Doha \\
\hline Per Capita Income & 7188.2 & 0.0 & 7188.2 & 0.6 & 0.5 & 1.2 & 0.1 \\
\hline General Entropy Index (0) & 35.7 & -0.1 & 35.7 & 0.3 & -0.1 & -0.3 & 0.0 \\
\hline General Entropy Index (1) & 48.4 & -0.1 & 48.4 & 0.2 & -0.1 & -0.6 & 0.0 \\
\hline Gini Index & 45.7 & -0.1 & 45.7 & 0.1 & -0.1 & -0.2 & 0.0 \\
\hline Poverty Headcount & 18.3 & -0.2 & 18.3 & -1.0 & -2.0 & -3.5 & -0.1 \\
\hline Poverty Gap & 4.8 & -0.2 & 4.8 & -0.8 & -1.6 & -3.4 & -0.1 \\
\hline Squared Poverty Gap & 1.9 & -0.2 & 1.9 & -0.8 & -1.3 & -3.3 & -0.1 \\
\hline Number of poor & 39253480 & -78507 & 39174973 & -374680 & -798764 & -1384164 & -48152 \\
\hline Urban area & Base & PRESIM & New base & ULIB & FLIBX & Full-Lib & Doha \\
\hline Per Capita Income & 9775.9 & 0.0 & 9775.9 & 0.8 & 0.3 & 1.1 & 0.0 \\
\hline General Entropy Index (0) & 38.5 & -0.1 & 38.5 & 0.1 & 0.3 & -0.4 & 0.1 \\
\hline General Entropy Index (1) & 52.9 & -0.1 & 52.8 & 0.0 & 0.3 & -0.6 & 0.1 \\
\hline Gini Index & 47.3 & 0.0 & 47.3 & 0.0 & 0.1 & -0.2 & 0.0 \\
\hline Poverty Headcount & 14.5 & -0.2 & 14.5 & -2.2 & -0.8 & -3.4 & 0.0 \\
\hline Poverty Gap & 4.1 & -0.1 & 4.1 & -1.5 & -0.1 & -2.8 & 0.1 \\
\hline Squared Poverty Gap & 1.8 & -0.1 & 1.8 & -1.4 & 0.1 & -2.9 & 0.1 \\
\hline Number of poor & 13322340 & -26645 & 13295695 & -287148 & -109962 & -454021 & 0 \\
\hline Rural area & Base & PRESIM & New base & ULIB & FLIBX & Full-Lib & Doha \\
\hline Per Capita Income & 5235.6 & 0.1 & 5240.8 & 0.2 & 0.9 & 1.4 & 0.1 \\
\hline General Entropy Index (0) & 25.0 & -0.1 & 25.0 & 0.0 & 0.0 & 0.0 & 0.0 \\
\hline General Entropy Index (1) & 30.3 & -0.2 & 30.2 & -0.2 & 0.1 & -0.2 & 0.0 \\
\hline Gini Index & 38.4 & -0.1 & 38.4 & 0.0 & 0.0 & 0.0 & 0.0 \\
\hline Poverty Headcount & 21.2 & -0.2 & 21.2 & -0.3 & -2.7 & -3.6 & -0.2 \\
\hline Poverty Gap & 5.3 & -0.3 & 5.3 & -0.4 & -2.4 & -3.8 & -0.2 \\
\hline Squared Poverty Gap & 2.1 & -0.3 & 2.1 & -0.4 & -2.1 & -3.6 & -0.2 \\
\hline Number of poor & 25931138 & -51862 & 25879276 & -87530 & -688798 & -930140 & -48150 \\
\hline
\end{tabular}

Notes: 1. Base values in the 1st column; percent changes for the following columns. Poverty indicators are computed using national poverty lines (WB, 2003). Poverty indicators are computed using national poverty lines (WB, 2003).

2. PRESIM = Pre-simulation scenarios entailing China's WTO accession, the completion of the UR-ATC commitment to abolish textiles and apparel quotas, and EU's enlargement to 25 members; ULIB = Unilateral liberalization; FLIBX = Full liberalization excluding Indonesia; Full-Lib = Full liberalization including Indonesia; Doha = Doha scenario 
Table 5: Macroeconomic results of alternative scenarios

\begin{tabular}{lrrrr}
\hline & Base & FLIBVAT & FLIB_2 & FLIB_3 \\
\hline Private Consumption & 1040.3 & 0.7 & 1.7 & 0.7 \\
Investment Demand & 324.7 & & & \\
Government Consumption & 132.2 & & & \\
Total Absorption & 1497.3 & 0.5 & 1.2 & 0.5 \\
Exports value & 566.0 & 5.8 & 6.5 & 6.0 \\
Imports value & 443.1 & 9.0 & 9.9 & 9.2 \\
Real GDP at Factor Costs & 1537.8 & 0.0 & 0.7 & 0.0 \\
Nominal GDP at Factor Costs & 1537.8 & 0.4 & 1.9 & 1.0 \\
Urban Agricultural Income & 113.1 & 3.3 & 5.0 & 1.8 \\
Rural Agricultural Income & 210.0 & 3.0 & 3.9 & 1.9 \\
Urban Non Agricultural Income & 183.0 & 1.4 & 2.1 & 2.3 \\
Rural Non Agricultural Income & 111.7 & 1.2 & 1.8 & 1.7 \\
Urban Unskilled Wage Income & 222.5 & 0.0 & 1.3 & 0.8 \\
Rural Unskilled Wage Income & 43.6 & 0.6 & 1.5 & 0.6 \\
Urban Skilled Wage Income & 77.0 & 0.5 & 1.3 & 0.9 \\
Rural Skilled Wage Income & 67.0 & 0.5 & 1.0 & 0.4 \\
Non Labor Income & 601.8 & -0.9 & 1.6 & 0.4 \\
Urban Unskilled Employment & 15.0 & & 1.5 & \\
Urban Skilled Employment & 17.5 & & 1.0 & \\
Rural Unskilled Employment & 34.2 & & 1.7 & \\
Rural Skilled Employment & 9.8 & & 1.1 & \\
Total Employment & 76.5 & & 1.4 & \\
\hline
\end{tabular}

Notes: 1.Base values in Rp. thousands of billions except employment outcomes in millions of workers; percent changes for the nonbase columns.

2. FLIB_2 = Full liberalization including Indonesia with flexible unemployment; FLIB_3 = Full liberalization including Indonesia with sector specific labor; FLIBVAT = Full liberalization including Indonesia with VAT rates adjustment as tax replacement scheme. 
Table 6: Social impact of alternative scenarios

\begin{tabular}{|c|c|c|c|c|}
\hline National level & Base & FLIBVAT & FLIB_2 & FLIB_3 \\
\hline Per Capita Income & 7188.2 & 0.8 & 1.7 & 1.0 \\
\hline General Entropy Index (0) & 35.7 & -0.1 & 0.1 & 0.3 \\
\hline General Entropy Index (1) & 48.4 & -0.1 & -0.3 & 0.4 \\
\hline Gini Index & 45.7 & -0.1 & 0.1 & 0.2 \\
\hline Poverty Headcount & 18.3 & -2.3 & -3.2 & -2.4 \\
\hline Poverty Gap & 4.8 & -2.3 & -3.4 & -2.1 \\
\hline Squared Poverty Gap & 1.9 & -2.0 & -3.7 & -2.2 \\
\hline Number of poor & 39174973 & -902032 & -1236696 & -961328 \\
\hline Urban area & Base & FLIBVAT & FLIB_2 & FLIB_3 \\
\hline Per Capita Income & 9775.9 & 0.6 & 1.4 & 1.1 \\
\hline General Entropy Index (0) & 38.5 & 0.3 & 0.4 & 0.3 \\
\hline General Entropy Index (1) & 52.8 & 0.3 & 0.0 & 0.4 \\
\hline Gini Index & 47.3 & 0.1 & 0.2 & 0.2 \\
\hline Poverty Headcount & 14.5 & -1.3 & -1.2 & -2.5 \\
\hline Poverty Gap & 4.1 & -0.5 & -2.0 & -2.1 \\
\hline Squared Poverty Gap & 1.8 & -0.5 & -2.5 & -2.2 \\
\hline Number of poor & 13295695 & -169782 & -164989 & -328554 \\
\hline Rural area & Base & FLIBVAT & FLIB_2 & FLIB_3 \\
\hline Per Capita Income & 5240.8 & 1.2 & 2.0 & 0.8 \\
\hline General Entropy Index (0) & 25.0 & 0.0 & 0.5 & 0.2 \\
\hline General Entropy Index (1) & 30.2 & 0.0 & 0.0 & 0.1 \\
\hline Gini Index & 38.4 & -0.1 & 0.3 & 0.1 \\
\hline Poverty Headcount & 21.2 & -2.8 & -4.1 & -2.4 \\
\hline Poverty Gap & 5.3 & -3.3 & -4.3 & -2.1 \\
\hline Squared Poverty Gap & 2.1 & -3.0 & -4.4 & -2.2 \\
\hline Number of poor & 25879276 & -732250 & -1071706 & -632774 \\
\hline
\end{tabular}

Notes: 1. Base values in the 1st column; percent changes for the following columns. Poverty indicators are computed using national poverty lines (WB, 2003).

2. FLIB_2 = Full liberalization including Indonesia with flexible unemployment; FLIB_3 = Full liberalization including Indonesia with sector specific labor; FLIBVAT = Full liberalization including Indonesia with VAT rates adjustment as tax replacement scheme. 
WPS3747

Table 7: Monte Carlo simulations on the social impact of alternative labor market closures

\begin{tabular}{lrrrrrrr}
\hline National level & Base & Full-Lib & Std. Dev. & FLIB_2 & Std. Dev. & FLIB_3 & Std. Dev. \\
\hline Per Capita Income & 7188.2 & 1.2 & 0.0 & 1.7 & 0.0 & 1.0 & 0.0 \\
General Entropy Index (0) & 35.7 & -0.3 & 0.6 & -0.3 & 0.7 & 0.2 & 0.3 \\
General Entropy Index (1) & 48.4 & -0.9 & 1.8 & -1.4 & 2.0 & 0.1 & 1.0 \\
Gini Index & 45.7 & -0.1 & 0.2 & -0.1 & 0.3 & 0.1 & 0.1 \\
Poverty Headcount & 18.3 & -3.2 & 0.3 & -4.0 & 0.5 & -2.5 & 0.1 \\
Poverty Gap & 4.8 & -3.4 & 0.4 & -3.9 & 0.6 & -2.2 & 0.1 \\
Squared Poverty Gap & 1.9 & -3.3 & 0.5 & -3.8 & 0.9 & -2.2 & 0.2 \\
\hline Urban area & Base & Full-Lib & Std. Dev. & FLIB_2 & Std. Dev. & FLIB_3 & Std. Dev. \\
\hline Per Capita Income & 975.9 & 1.1 & 0.1 & 1.4 & 0.1 & 1.1 & 0.0 \\
General Entropy Index (0) & 38.5 & -0.4 & 1.2 & -0.6 & 1.4 & 0.1 & 0.7 \\
General Entropy Index (1) & 52.8 & -1.2 & 2.8 & -1.8 & 3.2 & -0.1 & 1.6 \\
Gini Index & 47.3 & -0.2 & 0.5 & -0.3 & 0.6 & 0.1 & 0.3 \\
Poverty Headcount & 14.5 & -2.5 & 0.9 & -2.9 & 1.1 & -2.6 & 0.3 \\
Poverty Gap & 4.1 & -2.6 & 0.7 & -3.1 & 1.2 & -2.2 & 0.3 \\
Squared Poverty Gap & 1.8 & -2.6 & 0.9 & -3.3 & 1.7 & -2.3 & 0.4 \\
\hline Rural area & Base & Full-Lib & Std. Dev. & FLIB_2 & Std. Dev. & FLIB_3 & Std. Dev. \\
\hline Per Capita Income & 5240.8 & 1.4 & 0.0 & 2.0 & 0.1 & 0.8 & 0.0 \\
General Entropy Index (0) & 25.0 & 0.1 & 0.2 & 0.5 & 0.4 & 0.2 & 0.0 \\
General Entropy Index (1) & 30.2 & 0.1 & 0.2 & 0.2 & 0.7 & 0.3 & 0.0 \\
Gini Index & 38.4 & 0.0 & 0.1 & 0.2 & 0.2 & 0.1 & 0.0 \\
Poverty Headcount & 21.2 & -3.5 & 0.2 & -4.5 & 0.6 & -2.4 & 0.1 \\
Poverty Gap & 5.3 & -3.9 & 0.3 & -4.4 & 0.7 & -2.1 & 0.1 \\
Squared Poverty Gap & 2.1 & -3.8 & 0.5 & -4.1 & 1.1 & -2.1 & 0.1 \\
Number of experiments & & 98 & & 98 & & 99 & \\
\hline
\end{tabular}

Notes: Full-Lib = Full liberalization including Indonesia with fixed unemployment; FLIB_2 = Full liberalization including Indonesia with flexible unemployment; FLIB_3 = Full liberalization including Indonesia with sector specific labor; 


\section{Annex A: Structure of the Social Accounting Matrix}

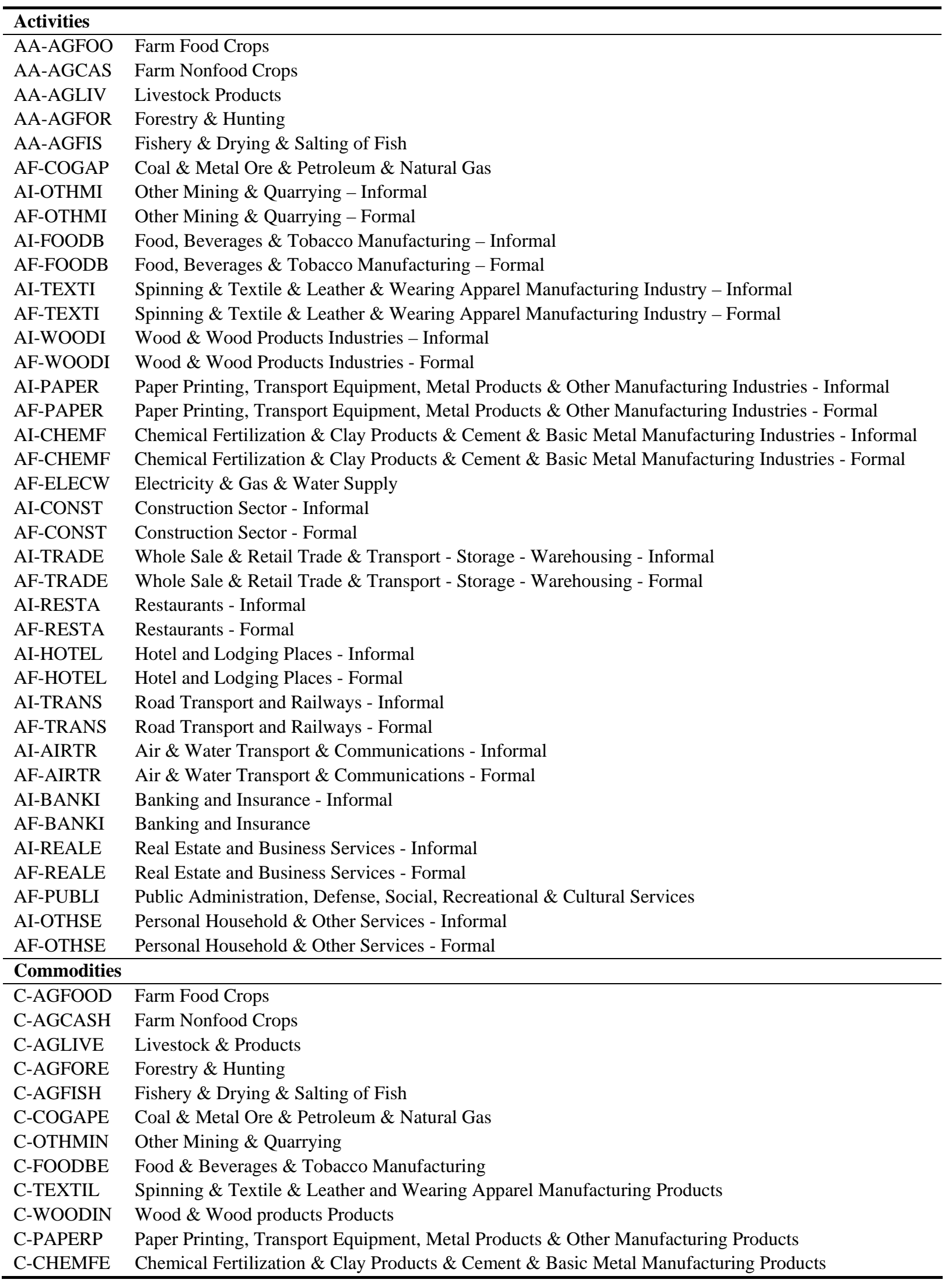




\begin{tabular}{|c|c|}
\hline \multicolumn{2}{|l|}{ Activities } \\
\hline C-ELECWA & Electricity \& Gas \& Water Supply \\
\hline C-CONSTR & Construction Sector \\
\hline C-TRADES & Whole Sale \& Retail Trade \& Transport - Storage - Warehousing \\
\hline C-RESTAU & Restaurants \\
\hline C-HOTELS & Hotel and Lodging Places \\
\hline C-TRANSP & Road Transport and Railways \\
\hline C-AIRTRN & Air \& Water Transport \& Communications \\
\hline C-BANKIN & Banking and Insurance \\
\hline C-REALES & Real Estate and Business Services \\
\hline C-PUBLIC & Public Administration, Defense, Social, Recreational \& Cultural Services \\
\hline C-OTHSER & Personal Household \& Other Services \\
\hline \multicolumn{2}{|r|}{ 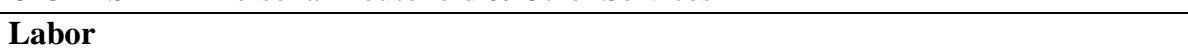 } \\
\hline LAB-UMU & Urban Male Unskilled Labor \\
\hline LAB-UMS & Urban Male Skilled Labor \\
\hline LAB-UFU & Urban Female Unskilled Labor \\
\hline LAB-UFS & Urban Female Skilled Labor \\
\hline LAB-RMU & Rural Male Unskilled Labor \\
\hline LAB-RMS & Rural Male Skilled Labor \\
\hline LAB-RFU & Rural Female Unskilled Labor \\
\hline LAB-RFS & Rural Female Skilled Labor \\
\hline \multicolumn{2}{|l|}{ Capital } \\
\hline CAP-LAND & Land \\
\hline CAP-HOUS & Owner Occupied Housing \\
\hline CAP-ORUR & Unincorporated Rural Capital \\
\hline CAP-OURB & Unincorporated Urban Capital \\
\hline CAP-PRIV & Incorporated Domestic Private Capital \\
\hline CAP-PUBL & Incorporated Domestic Public Capital \\
\hline CAP-FORE & Incorporated Foreign Capital \\
\hline \multicolumn{2}{|l|}{ Institutions } \\
\hline HH-AGEMP & Agricultural Households - Employees \\
\hline HH-AGL05 & Agricultural Households - Operators 0.0 to 0.5 ha \\
\hline HH-AGL10 & Agricultural Households - Operators 0.5 to 1.0 ha \\
\hline HH-AGLBG & Agricultural Households - Operators more than 1.0 ha \\
\hline HH-LORUR & Non Agricultural Households - Lower Level Rural \\
\hline HH-NLRUR & Non Agricultural Households - Non Labor Force Rural \\
\hline HH-HIRUR & Non Agricultural Households - Higher Level Rural \\
\hline HH-LOURB & Non Agricultural Households - Lower Level Urban \\
\hline HH-NLURB & Non Agricultural Households - Non Labor Force Urban \\
\hline HH-HIURB & Non Agricultural Households - Higher Level Urban \\
\hline ENT & Companies \\
\hline GOV & Government \\
\hline VATAX & Value Added Tax \\
\hline STAX & Sales Tax \\
\hline IMPTAX & Import Tax \\
\hline DIRTAX & Direct Tax \\
\hline ROW & Rest of the World \\
\hline SAVINV & Savings-Investment Account \\
\hline
\end{tabular}


Annex B: Terms of trade shocks and import tariff cuts

Export Price Change relative to CPI (in percent)

\begin{tabular}{lccccccc}
\hline & PRESIM & FLIB & FLIBX & DHSDT & DHSDTX & DHALL & DHALLX \\
\hline C-AGFOOD & -0.189 & 0.340 & 0.862 & 0.124 & 0.077 & 0.109 & 0.055 \\
C-AGCASH & -0.626 & -1.703 & -1.350 & -0.522 & -0.516 & -0.585 & -0.559 \\
C-AGLIVE & 0.002 & 1.614 & 1.519 & 0.271 & 0.181 & 0.262 & 0.178 \\
C-AGFORE & 0.210 & 1.198 & 0.206 & -0.134 & -0.214 & -0.058 & -0.179 \\
C-AGFISH & 0.324 & 0.036 & -0.554 & -0.091 & -0.095 & -0.037 & -0.041 \\
C-COGAPE & -0.172 & -1.248 & -1.786 & -0.353 & -0.301 & -0.397 & -0.321 \\
C-OTHMIN & -0.023 & 0.759 & -0.493 & 0.309 & 0.317 & 0.270 & 0.280 \\
C-FOODBE & 0.063 & 1.466 & 0.640 & 0.095 & 0.082 & 0.107 & 0.089 \\
C-TEXTIL & -3.776 & -0.115 & 0.102 & 0.178 & 0.199 & 0.170 & 0.192 \\
C-WOODIN & 0.145 & 1.020 & 0.001 & -0.066 & -0.094 & -0.029 & -0.075 \\
C-PAPERP & 0.023 & -0.610 & -0.741 & -0.152 & -0.152 & -0.152 & -0.149 \\
C-CHEMFE & 0.017 & -0.838 & -0.848 & -0.220 & -0.181 & -0.235 & -0.193 \\
C-ELECWA & 0.078 & 0.838 & -0.285 & -0.084 & -0.092 & -0.067 & -0.084 \\
C-CONSTR & 0.064 & 0.108 & -0.405 & -0.095 & -0.105 & -0.085 & -0.098 \\
C-TRADES & 0.156 & 1.759 & 0.218 & 0.036 & 0.012 & 0.067 & 0.030 \\
C-RESTAU & 0.040 & 0.925 & 0.266 & 0.048 & 0.034 & 0.062 & 0.042 \\
C-HOTELS & 0.040 & 0.925 & 0.266 & 0.048 & 0.034 & 0.062 & 0.042 \\
C-TRANSP & 0.099 & 0.977 & -0.123 & -0.030 & -0.041 & -0.015 & -0.031 \\
C-AIRTRN & 0.052 & 0.211 & -0.526 & -0.127 & -0.133 & -0.121 & -0.128 \\
C-BANKIN & 0.082 & 1.552 & 0.061 & 0.007 & -0.016 & 0.036 & 0.002 \\
C-REALES & 0.077 & 1.026 & 0.019 & 0.002 & -0.014 & 0.022 & -0.002 \\
C-PUBLIC & -0.001 & 1.367 & 0.050 & 0.033 & 0.012 & 0.062 & 0.029 \\
C-OTHSER & 0.187 & 1.899 & 0.302 & 0.049 & 0.022 & 0.082 & 0.042 \\
\hline
\end{tabular}

Import Price Change relative to CPI (in percent)

\begin{tabular}{lccccccc}
\hline & PRESIM & FLIB & FLIBX & DHSDT & DHSDTX & DHALL & DHALLX \\
C-AGFOOD & -0.054 & 3.829 & 3.148 & 0.897 & 0.991 & 0.770 & 0.924 \\
C-AGCASH & 0.005 & 9.681 & 9.905 & 4.237 & 4.305 & 4.125 & 4.247 \\
C-AGLIVE & -0.316 & 0.236 & -0.418 & 0.683 & 0.701 & 0.614 & 0.662 \\
C-AGFORE & -0.236 & -1.929 & -2.203 & -0.601 & -0.549 & -0.648 & -0.558 \\
C-AGFISH & -0.110 & -1.159 & -1.787 & -0.527 & -0.463 & -0.563 & -0.468 \\
C-COGAPE & -0.303 & -2.350 & -2.820 & -0.595 & -0.521 & -0.686 & -0.573 \\
C-OTHMIN & -0.264 & -1.477 & -2.135 & -0.318 & -0.253 & -0.390 & -0.279 \\
C-FOODBE & -0.449 & 0.819 & 0.040 & 1.027 & 1.043 & 0.956 & 0.990 \\
C-TEXTIL & 0.029 & -1.917 & -2.623 & -0.336 & -0.280 & -0.455 & -0.370 \\
C-WOODIN & -0.174 & -1.872 & -2.408 & -0.517 & -0.493 & -0.556 & -0.511 \\
C-PAPERP & -0.036 & -1.904 & -2.505 & -0.456 & -0.440 & -0.497 & -0.466 \\
C-CHEMFE & -0.061 & -2.009 & -2.672 & -0.478 & -0.460 & -0.544 & -0.515 \\
C-ELECWA & -0.240 & -1.956 & -2.507 & -0.626 & -0.602 & -0.654 & -0.609 \\
C-CONSTR & -0.281 & -2.272 & -2.760 & -0.679 & -0.665 & -0.708 & -0.681 \\
C-TRADES & -0.091 & -1.416 & -2.125 & -0.557 & -0.555 & -0.561 & -0.555 \\
C-RESTAU & -0.354 & -2.119 & -2.716 & -0.708 & -0.693 & -0.735 & -0.704 \\
C-HOTELS & -0.354 & -2.119 & -2.716 & -0.708 & -0.693 & -0.735 & -0.704 \\
C-TRANSP & -0.321 & -2.136 & -2.650 & -0.676 & -0.641 & -0.716 & -0.656 \\
C-AIRTRN & -0.336 & -2.062 & -2.613 & -0.639 & -0.615 & -0.671 & -0.630 \\
C-BANKIN & -0.331 & -1.990 & -2.624 & -0.683 & -0.673 & -0.705 & -0.680 \\
C-REALES & -0.300 & -1.910 & -2.541 & -0.661 & -0.661 & -0.683 & -0.676 \\
C-PUBLIC & -0.306 & -2.266 & -2.708 & -0.683 & -0.654 & -0.726 & -0.667 \\
C-OTHSER & 0.187 & 1.899 & 0.302 & 0.049 & 0.022 & 0.082 & 0.042 \\
\hline
\end{tabular}




\section{Change in power of import tax (in percent)}

WPS3747

\begin{tabular}{lccccccc}
\hline & PRESIM & FLIB & FLIBX & DHSDT & DHSDTX & DHALL & DHALLX \\
\hline C-AGFOOD & 0.000 & -2.444 & 0.000 & 0.000 & 0.000 & 0.000 & 0.000 \\
C-AGCASH & 0.000 & -1.224 & 0.000 & 0.000 & 0.000 & 0.000 & 0.000 \\
C-AGLIVE & 0.000 & -3.177 & 0.000 & 0.000 & 0.000 & 0.000 & 0.000 \\
C-AGFORE & 0.000 & -0.225 & 0.000 & 0.000 & 0.000 & 0.000 & 0.000 \\
C-AGFISH & 0.000 & -4.490 & 0.000 & 0.000 & 0.000 & 0.000 & 0.000 \\
C-COGAPE & 0.000 & -2.027 & 0.000 & 0.000 & 0.000 & 0.000 & 0.000 \\
C-OTHMIN & 0.000 & -1.483 & 0.000 & 0.000 & 0.000 & 0.000 & 0.000 \\
C-FOODBE & -0.071 & -8.460 & 0.000 & -0.300 & 0.000 & -0.300 & 0.000 \\
C-TEXTIL & 0.000 & -7.414 & 0.000 & 0.000 & 0.000 & 0.000 & 0.000 \\
C-WOODIN & 0.000 & -5.154 & 0.000 & 0.000 & 0.000 & 0.000 & 0.000 \\
C-PAPERP & -0.139 & -4.601 & 0.000 & -0.022 & 0.000 & -0.040 & 0.000 \\
C-CHEMFE & -0.011 & -4.558 & 0.000 & -0.177 & 0.000 & -0.193 & 0.000 \\
\hline
\end{tabular}




\section{Annex C: Microsimulation techniques applied to the evaluation of poverty reduction policies (Cogneau, Grimm \& Robilliard, 2003)}

Most of the common macro models used to analyze distributional issues usually rely on the definition of representative household groups characterized by different combinations of factor endowments and possibly different behaviors. The heterogeneity of the population of households is thus integrated in a scarce and unsatisfactory way, where the inequality modeled is essentially the inequality between the representative groups. This explains why traditional macroeconomic models may appear unsatisfactory in dealing with distributional issues. Different approaches that rely on full household/individual samples have been developed recently to overcome this difficulty. They differ in how they account for micro behaviors and in the degree of integration of the macro and micro "stories."

The term microsimulation spans a number of different approaches used in social sciences. Their common denominator is to focus primarily on the economic behavior of agents and investigate the impact of public policy and shocks at the micro level. These models typically take representative samples of micro agents (households or firms) and measure the effect of government policy on these samples. The field originated from a paper by Orcutt (1957) who was concerned that macro-economic models had little to say about the impact of government policy on the distribution of income across agents in the economy. In developed countries, microsimulation techniques are now extensively used to evaluate the impact of pension systems, social security and fiscal reforms. The application of microsimulation techniques to developing countries however raises a number of specific problems. 


\section{WPS3747}

The micro-units examined in the microsimulation models used to evaluate poverty reduction policies, of particular interest to us here, are individuals and households. In most cases, these models focus on monetary poverty and income distribution. As a result, all mechanisms related to income generation - such as wage formation, occupational choice, labor supply - are central. Another key characteristic of microsimulation models is their ability to produce meaningful aggregates (either at the regional or national level), calculated by adding-up the results obtained at the individual level. This quality relates to the use of representative household samples, the aim being to ensure consistency between macroeconomic reasoning and poverty evaluation.

The basic principle underlying microsimulation models is to take the household sample as a reference population to which economic shocks and, in the case of dynamic models, demographical processes such as births, deaths, migration etc., is applied. In the case of static models, the 'final' population is the same as the reference population, but household income and consumption (or any other relevant characteristic at the household level that has been incorporated in the model) have changed. In dynamic models, the simulated population is different because demographical processes change its structure. In both cases, the aim is to compare the distribution of income or consumption (or any other welfare measure) before and after the simulated shock, using standard measures and methods for poverty analysis.

In order to evaluate poverty reduction policies, microsimulation models are typically linked to a macro-economic framework, which can be more or less comprehensive. The term macro-micro model will be used to refer to the combination of a microsimulation model with a macro-economic framework.

Some key characteristics seem relevant to describe and classify macro-micro models used to evaluate poverty reduction policies. These characteristics relate either to the features 


\section{WPS3747}

of the micro simulation 'module', or to those of the macro-economic framework, or to the characteristics of the linkage between these two levels.

Concerning the microsimulation module, a fundamental feature is whether agents' behaviors are taken into account. When this is not the case, the microsimulation module contains at least an 'accounting' income equation. We shall refer to this type of model using the term 'micro-accounting' model. When micro-economic behaviors are represented, the type of behavior constitutes another discriminating feature of micro simulation models. For instance, some models focus on labor supply and occupational choices, while others represent decisions concerning schooling, migration or consumption. The representation of microeconomic behavior can be based on a reduced or a structural specification. By definition, reduced specifications are derived from structural neoclassical models of constrained optimization and have these models' standard properties. However, given their reduced form, they cannot explicitly account for the endogenous phenomena of decision-making, segmentation and/or rationing at work at the micro-economic level.

A second characteristic that distinguishes macro-micro models relates to the modeling of phenomena at the aggregate level, i.e. establishing whether there is macro-economic closure and, if so, defining its characteristics. First, a distinction can be made between models with no closure, which address first-round effects or measures with low feedback, and 'closed' models that take into account the general equilibrium effects through price variations or macro-economic quantities. Prices determination mechanism can then either be 'integrated' into the microsimulation model, or formalized in an 'independent' aggregate model that feeds the microsimulation, in what is then referred to as a sequential model.

The two characteristics mentioned above (reduced versus structural, sequential versus integrated) are in fact not entirely independent. Integrating macro-economic closure into a microsimulation model imposes a structural specification of micro-economic behavior. 
A final criterion that can be used to classify microsimulation models is the time dimension. Demo-economic models are generally developed to study the impact of a change in demo-economic behavior and therefore focus on the dynamic aspects and on modeling demographic processes. In contrast, static models designed to examine the short or mediumterm impacts of changes in the economic environment are based on a more comprehensive modeling of short or medium-term behavior, in particular with respect to the functioning of markets for goods and factors.

Using relevant combinations of the classification criteria presented above, different approaches can be distinguished which we will now describe, outlining their advantages and their limits.

\section{Micro-accounting and disaggregated CGE models}

This first approach basically corresponds to a more extensive disaggregation of a standard multi-sector and multi-market model.

The construction of any microsimulation model applied to poverty analysis starts by computing the reference income distribution for the sample of households using the information contained in the household survey. This can be a delicate exercise, particularly when it comes to collecting data on income from independent activities. Once the distribution of income has been established, household income can be disaggregated into different sources (wage income, agricultural income, income from informal independent activities, transfers etc.). If the structure of household consumption is available, specific price indexes for each household can also be constructed. This allows taking into account differences in budget shares, and in particular capturing the fact that poor households tend to have bigger food shares than rich ones. 
At the macro level, the evolution of prices corresponding to the different types of income can be extracted from a CGE-type macro model. For example, the evolution of factor prices following a change in the economic environment can be used as the basis for a microsimulation exercise, as long as it is possible to match the sources of income of households in the sample with the factors contained in the Social Accounting Matrix, and thereby in the CGE model. This matching raises a number of issues because Social Accounting Matrices are mainly built using national accounts and are likely to use nomenclatures different from those used in the household surveys (see Robilliard and Robinson (1999).

Once the structures of income and consumption of the sample households has been determined in accordance with the structure of the macro-economic model, it is relatively simple to proceed with the microsimulation accounting exercise. For instance, if one assumes that agricultural income went up by 10 per cent, it is relatively straightforward to recompute household incomes using that information and compare the new income distribution with the initial one.

The limits of this type of model are inherent to the assumption that households do not respond to changes in the price system. Indeed, it implicitly assumes that households hold fixed shares of factors for which only returns are liable to change. This hypothesis is particularly debatable in the case of labor supply and is likely to limit the scope of this type of model to cases where adjustments on the labor market are small.

\section{Sequential approach and reduced models}

Introducing households' behaviors constitutes a more advanced stage of microsimulation. As we pointed out above, the formalization of micro-economic behavior can be reduced or structural. One possible approach is based on a 'reduced-form' 
microsimulation module that describes the income generation process for a sample of households, taking into account occupational choices.

This approach is inspired by a model developed by Bourguignon, Fournier and Gurgand (2001) and applied to analyzing the evolution of income distribution in Taiwan from 1979 to 1994 . The microsimulation model is based on the representation of income generation by a model of individual occupational choice and wage and profit equations. This framework has been extended and linked to a standard CGE model to analyze the social impact of the financial crisis in Indonesia (Robilliard, Bourguignon and Robinson 2001). The two models are used sequentially: the CGE model generates vectors of price, wages and employment which are then transferred to the microsimulation model, which in turn generates a new distribution of incomes, consistent with the aggregates given by the CGE model.

The advantage of this type of approach is that it is based on a micro-econometric model of household behavior that takes into account decisions concerning production and labor supply. Nevertheless, one of the problems posed by this approach is the consistency between the aggregate and micro-economic representations of behavior and the functioning of the factor markets.

\section{Integrated approach and structural models}

The introduction of a structural specification of household decisions permits capturing more complex behaviors and allows implementing an integrated framework. Compared to the sequential approach where micro-economic behavior need to be specified twice (in an aggregated form in the macro module and in a disaggregated form in the microsimulation module), the integrated approach has the advantage of being completely consistent in terms of the specification of micro-economic behavior: all the flows that are related to household 


\section{WPS3747}

behavior (like labor supply, consumption, etc.) are computed by adding-up results obtained at the household level, not by using an aggregate labor supply or consumption function.

One key characteristic of this type of approach is to focus more on the microeconomic side of the model, on the basis of a comprehensive structural modeling of occupational choices, income generation and consumption decisions. To our knowledge, Cogneau (1999 and 2001) was the first to develop a microsimulation model of household income within a general equilibrium framework. This model was used to study the labor market in Antananarivo. In line with it, a general equilibrium microsimulation model was developed and applied to the Malagasy economy as a whole in order to analyze the impact of different development strategies on poverty and income distribution (Cogneau and Robilliard 2001).

In terms of consistency, this type of approach appears more satisfactory than the sequential approach described above, but the complexity of the structural specifications makes an exhaustive disaggregation of goods and sectors more difficult, due to the intrinsic econometric difficulties posed by estimating systems of equations. Hence, contrary to the previous approaches, this type of model must be content with a less sophisticated representation of the macro-economic and multi-market framework. This aspect limits the scope of the approach to cases where inter-sectoral reallocation does not play a central role. For example, the economic impact of certain macro-economic or liberalization policies generally depends on the position of the goods produced by the economy vis-à-vis foreign trade. One of the contributions of applied general equilibrium models stems from their ability to take into account structural effects by disaggregating activities and goods. From that perspective, the integrated structural approach is relatively better adapted to exploring demoeconomic issues or general growth strategies for instance, or targeted policies such as labor market interventions or price policies. Another limit has to do with the fact that, although it 


\section{WPS3747}

may be possible in theory, it is hard in practice to devise a full structural econometrical model of household behavior, including production, labor supply, consumption, schooling, and migration decisions. The model either has to focus on the features of behavior most relevant to the policy question under review, or use a 'piecemeal modeling' approach in the spirit of Orcutt's microsimulation analysis.

\section{Dynamic models}

One way of explicitly taking into account the temporal dimension of economic policies as well as the heterogeneity of individual behavior and resources is to integrate a household income microsimulation model (as presented above) into a dynamic microsimulation model able to project the population structure and the accumulation of human and possibly physical capital through time.

In contrast with the other approaches described above, a drawback of the dynamic microsimulation model remains the lack of hypotheses concerning macro-economic closures and the long term evolution of the economy and the structure of economic growth. Much effort will be needed to resolve this problem in a satisfactory manner. Furthermore, the model parameters are generally estimated using cross section data, which hampers the modeling of behavioral changes or phenomena such as consumption smoothing. 